Discussion Paper No. 15-032

\title{
R\&D Policies for Young SMEs: Input and Output Effects
}

Dirk Czarnitzki and Julie Delanote

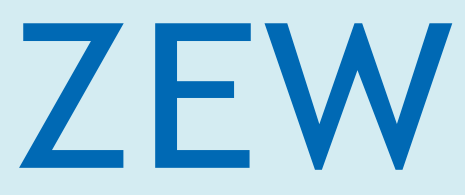

Zentrum für Europäische Wirtschaftsforschung $\mathrm{GmbH}$ Centre for European Economic Research 
Discussion Paper No. 15-032

\section{R\&D Policies for Young SMEs: \\ Input and Output Effects}

Dirk Czarnitzki and Julie Delanote

Download this ZEW Discussion Paper from our ftp server:

http://ftp.zew.de/pub/zew-docs/dp/dp15032.pdf

Die Discussion Papers dienen einer möglichst schnellen Verbreitung von neueren Forschungsarbeiten des ZEW. Die Beiträge liegen in alleiniger Verantwortung der Autoren und stellen nicht notwendigerweise die Meinung des ZEW dar.

Discussion Papers are intended to make results of ZEW research promptly available to other economists in order to encourage discussion and suggestions for revisions. The authors are solely responsible for the contents which do not necessarily represent the opinion of the ZEW. 


\title{
R\&D policies for young SMEs: input and output effects ${ }^{1}$
}

\author{
— revised version is forthcoming in Small Business Economics —
}

\author{
Dirk Czarnitzki ${ }^{a}$ and Julie Delanote ${ }^{b}$
}

\begin{abstract}
a) KU Leuven, Dept. of Managerial Economics, Strategy and Innovation, Belgium; Center for R\&D Monitoring (ECOOM) at KU Leuven; and ZEW Mannheim, Germany

b) KU Leuven, Dept. of Managerial Economics, Strategy and Innovation, Belgium; Center for R\&D Monitoring (ECOOM) at KU Leuven; and ZEW Mannheim, Germany
\end{abstract}

February 2015

\begin{abstract}
This paper evaluates the current focus of EU policy makers on small and medium-sized, young independent firms in high-tech sectors. Therefore, the effect of subsidies on both R\&D input and R\&D output is compared between independent high-tech young firms (NTBFs), independent low-tech young firms (LTBFs) and their non-independent counterparts. A treatment effects analysis reveals that full crowding-out with regard to public funding is rejected for all firm types. However, the treatment effect is highest for independent high-tech firms. The indirect effect of subsidies on R\&D output is evaluated within a patent production framework. These results show that independent high-tech firms have no lower output effects than other firms and thus suggest that the current policy focus on certain firm types is not ineffective.
\end{abstract}

Keywords: R\&D, subsidies, NTBFs, policy evaluation, treatment effects, patents

JEL Classification: $\mathrm{H} 25, \mathrm{M} 13, \mathrm{O} 31, \mathrm{O} 38$

\section{Contact details:}

Dirk Czarnitzki, KU Leuven, Faculty of Business and Economics

Naamsestraat 69

3000 Leuven, Belgium

E-Mail: dirk.czarnitzki@kuleuven.be

Julie Delanote, KU Leuven, Faculty of Business and Economics

Naamsestraat 69

3000 Leuven, Belgium

E-Mail: julie.delanote@kuleuven.be

\footnotetext{
${ }^{1}$ The authors like to thank the participants of the Druid Conference, Barcelona (2013); the 4th IZA workshop on entrepreneurship research, San Francisco (2013) and the 4th European conference on corporate R\&D and innovation (Concordi-2013), Seville for their valuable comments
} 


\section{Introduction}

There is a widespread belief that innovation activities of young, small and medium-sized enterprises (SMEs) might constitute the main driver of technological change and future growth (Veugelers, 2008; Schneider and Veugelers, 2010; Czarnitzki and Delanote, 2013). The increased attention from both scholars and policy makers towards these firms is not only rooted in the expectation of a potential direct contribution to economic growth, but also because of their expected indirect positive effects on large incumbent firms and their ability to create new markets. However, even among young SMEs the potential to successfully innovate may be heterogeneous. The effects on growth for example have been found to be most important in high-tech sectors. Audretsch (1995) for example, following upon Dunne et al. (1988) who found differences in growth rates across different industries, touches upon the importance of sectoral differentiation. The small start-ups active in a highly innovative environment seem to perform better than the ones in a low-tech environment. In this line of research, Westhead and Cowling (1995) and Almus and Nerlinger (1999) found that the new technology based firms (NTBFs), i.e. independent, young firms in high-tech sectors, showed the highest growth rates. Increasingly, scholars focused on these firms in high-tech sectors as incubators of economic progress (see e.g. Bartelsman et al., 2004; Calvo, 2006; Colombo and Grilli, 2010; Cozza et al., 2012).

This firm heterogeneity also gained increasing attention under the flagship initiative 'Innovation Union', established in context of the 'Europe 2020' targets (EC-DG Research and Innovation, 2011). Next to acknowledging the potentially important role of certain types of firms for technological change and economic growth, policy also supports the innovation activities of firms in order to overcome specific constraints faced disproportionately by these firms. The focus on specific types of firms also fits within the objective to provide 'less and better' state aid. Moncada et al. (2010) state that at least size, age, innovativeness and sectoral differentiation should play an important role in the choice of policy targets. The authors claim that the granting process of innovation subsidies should be oriented towards small, young, high-tech innovators.

A main reason is that the smallest and youngest companies are expected to suffer more from the well-known market failures such as a weak appropriability (Schumpeter, 1942; Nelson, 1959; Arrow, 1962) and uncertainty (Pindyck, 1991; Dixit and Pindyck, 1994) that lead to information asymmetries between firms and external suppliers of finance and result in un- 
derinvestment in R\&D (Arrow, 1962; Stiglitz and Weiss, 1981). The hypothesis that especially small, young innovators, and more specifically independent, high-tech ones, are seriously hampered in their innovation activities is confirmed in literature (Lerner, 1999, 2002; Evans and Jovanovic, 1989; Holtz-Eakin et al., 1994b,a; Czarnitzki and Hottenrott, 2011; Hall and Lerner, 2010). Himmelberg and Petersen (1994) and Carpenter and Petersen (2002), focusing on independent high-tech, small and young firms conclude that these firms are most financially constrained. Westhead and Storey (1997) explicitly compare the extent to which most technologically sophisticated small firms are more financially constrained than less technologically sophisticated ones and find that the former are more impeded in growth due to financial constraints. Goodacre and Tonks (1995) state that innovation in high-tech industries is more likely to be of a new sort because of which it is more difficult for financiers to evaluate the investment. Storey and Tether (1998) focus specifically on NTBFs and emphasize their higher need of external financing ${ }^{2}$, and others discuss their high innovative performance and growth (Storey and Tether, 1998; Colombo and Grilli, 2010; Licht and Nerlinger, 1998; Almus and Nerlinger, 1999).

Most scholars focus on independent young firms as non-independent firms are assumed to benefit from their parent companies or the group of firms they are associated with. That independent firms would be more in need of external funding is already suggested multiple times in literature. In general, Hoshi et al. (1991), Schaller (1993) and Czarnitzki and Hottenrott (2011) confirm that large internal capital resources reduce underinvestment problems, suggesting that this is even more true for $R \& D$ investments. In addition, especially small and young firms have limited access to internal funds as they cannot use earlier profit accumulations or a steady cash inflow from a broad and established product portfolio for financing their R\&D projects (see also e.g. Berger and Udell, 2002; Carpenter and Petersen, 2002; Cassar, 2004).

The focus on these specific types of firms also gained increasing attention of several European countries. In Germany, for example, the 'high-tech strategy 2020' explicitly focuses on key technologies as being the so-called 'drivers of innovation and the basis for new products, processes and services' (BMBF (Federal Ministry of Education and Research), 2010). In addition, as also specified by the European Commission, autonomous SME's are distinguished from non-independent firms and the focus of several different policy measures is on

\footnotetext{
${ }^{2}$ NTBFs are, since the introduction of this term by the Arthur D. Little Consulting Group, an intensely studied type of firms (Little, 1977).
} 
the former group (European Commission, 2008). Although the literature suggests a higher lack of financing for these firms and governments seem to acknowledge this, there is no elaborated evaluation yet on whether these firms show higher treatment effects when receiving subsidies.

In order to evaluate whether the subsidy granting process to young SMEs should be determined by independence and sectoral differentiation, we compare the impact of subsidies between four different types of young SMEs, (i) independent and high-tech (henceforth labeled as 'NTBFs'), (ii) non-independent, high-tech, ('group NTBFs') (iii) independent and low-tech, and ('LTBFs') (iv) non-independent, low-tech ('group LTBFs'). Table 1 graphically presents the four groups of firms analyzed in this study and recapitulates the differences between the types of firms.

Table 1: Overview on the studied firm types as part of the population

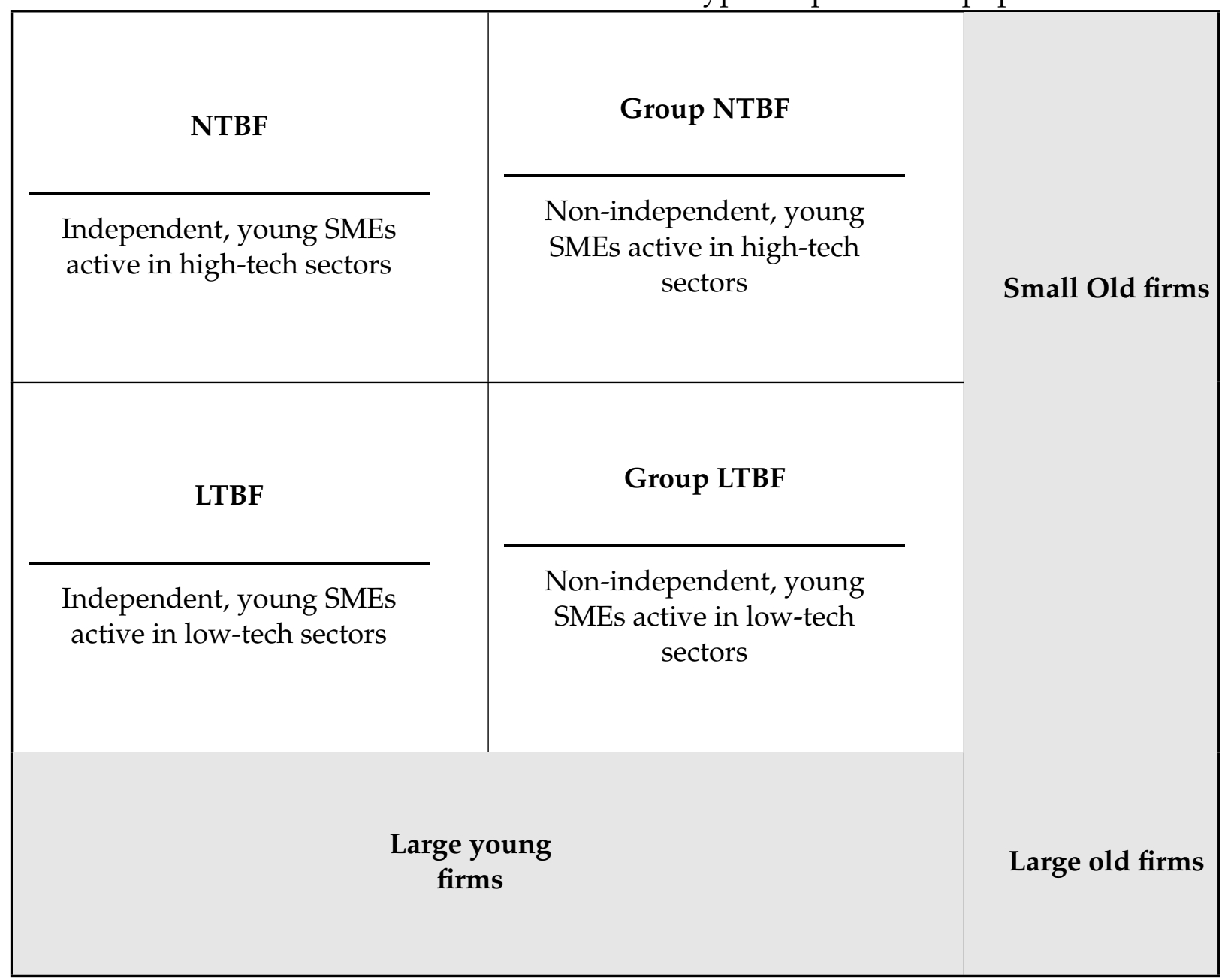


We evaluate the impact of direct R\&D subsidies granted to companies on several R\&D input measures and patents as R\&D output measure. The remainder of the paper is organized as follows: sections 2 and 3 review the evaluation literature and outline the econometric method used for both the input and output analysis, section 4 discusses the data used and presents descriptive statistics and section 5 presents the empirical results. Finally, a concluding section summarizes the findings and discusses policy implications.

\section{Subsidy input evaluation}

We first evaluate the impact of direct R\&D grants on innovation input. It is possible that the subsidies are subject to crowding-out effects. This might happen if firms replace their privately financed R\&D by the public funds. Furthermore, the empirical analysis could reveal heterogeneity in treatment effects among different firm types. For instance, many innovation subsidies to young SMEs are oriented towards independent firms. If our study, however, would show higher treatment effects for non-independent firms, i.e. those having parent companies or being associated with groups, it would suggest a misallocation of public resources.

In order to measure the effect of public support on R\&D input, several econometric models were proposed. However, estimating the effect of public subsidies is not that straightforward. Firms receiving a subsidy are presumably different from companies that do not receive a subsidy. A first difference already emerges at the application stage as some firms might be more likely to apply for public funding than others. Some firms might consider the administrative burden or the information sharing through the submission of research proposals as reasons to refrain from applying for a subsidy. In addition, there is a possibility that the funding agencies follow a picking-the winner strategy with respect to the firms that applied for a subsidy. In other words, firms might have some characteristics that make them more attractive to governments for funding. As a consequence, funding cannot be considered as a random process and this selection should be accounted for when evaluating subsidy schemes. In order to evaluate the impact of subsidies on the R\&D investment of the different firm types, caliper matching is performed in this study. Thus, we do not use a random control group, but non-subsidized firms that are similar to the subsidy recipients in several observed characteristics. 


\subsection{Literature review}

The impact of R\&D policies on firms' innovation behavior has already been extensively covered in the economic literature. The main focus in literature is on input additionality of subsidies. As a consequence, most of the literature addressed the issue of crowding-out effects of subsidized R\&D. David et al. (2000), Cerulli (2010) and Zúñiga Vicente et al. (2014) survey the literature on subsidy effects and find that, in general, the results of the reviewed literature vary; possibly also due to different data sources and methods.

Among the studies reviewed in the surveys, some focus on SMEs. Wallsten (2000), for example, uses a 3SLS approach in order to evaluate the effect of grants to SMEs in the context of the SBIR program. At first sight, he finds crowding-out of firm-financed R\&D spending dollar for dollar. However, Wallsten (2000) remarks that this result could be simply due to the fact that firms would have cut back their $R \& D$ expenditures in case no public funding was available. In other words, the R\&D grants may have allowed firms to continue their R\&D at a constant level rather than cutting it back.

Alecke et al. (2012) apply a matching estimator any find that SMEs, especially the microsized firms, show an increase in R\&D intensity as a result of subsidies. Alecke et al. (2012) also find that subsidies increase the probability of patent applications.

While the above studies focus on SMEs, the impact of subsidies on NTBFs has not been discussed extensively in the literature so far. Some studies evaluated the effect of subsidies on output measures. Colombo et al. (2012) for example show that especially young NTBFs grow more after receiving public funds and especially if these are allocated through a selective evaluation process. Colombo et al. (2011) and Grilli and Murtinu (2012) focus more specifically on R\&D subsidies and find that TFP growth of NTBFs is only enhanced if subsidies are provided competitively and if they aim at enhancing R\&D investments.

Apart from the current study, there are, to our knowledge, no papers that study the effect of innovation subsidies on R\&D input of NTBFs. Neither exist studies that investigate the different subsidy effects on NTBFs, Group NTBFs, LTBFs and Group LTBFs.

\subsection{Methodology}

In this study, we apply Caliper Matching. The technique of matching has, among others, been discussed by Angrist (1998); Dehejia and Wahba (1999); Heckman et al. (1998); Lechner (2000). In the context of this paper, matching tries to address the following question: “What is 
the effect of a subsidy grant on a subsidized firm?". Thus we estimate the difference between the actual observed R\&D of the subsidized firms and the counterfactual situation, where these firms would have not gotten subsidized. The 'average treatment effect on the treated', $\alpha^{\mathrm{TT}}$, can be written as:

$$
\alpha^{\mathrm{TT}}=\mathrm{E}\left(\mathrm{Y}^{\mathrm{T}} \mid \mathrm{S}=1\right)-\mathrm{E}\left(\mathrm{Y}^{\mathrm{C}} \mid \mathrm{S}=1\right)
$$

where $Y^{T}$ denotes the treatment outcome and $Y^{C}$ the counterfactual outcome. $S$ takes the value 1 if the firm is subsidized and zero otherwise. However, it is impossible to observe $Y^{C}$ because it is impossible to observe a treated firm without treatment. Therefore, this counterfactual outcome has to be estimated and is in this context constructed based upon a control group of non-subsidized firms. The idea is to balance the sample of subsidized firms and comparable non-subsidized firms. The remaining differences in outcomes between the matched subsidized and non-subsidized firms can then be attributed to the received treatment.

When performing matching, we replicate the conditions of an experiment to the best possible extent. Therefore, we determine a broad set of characteristics, $X$, that should be similar among firms to be matched. In other words, we compare the treated firm with an untreated firm that is basically identical to the treated firm with respect to the characteristics that we define. This set of characteristics should be exhaustive. Rubin (1977) introduced this as the Conditional Independence Assumption (CIA), which stipulates that the treatment and the outcome of this treatment are independent for the observations having the same set of exogenous characteristics. If this CIA is satisfied, the following equation is valid:

$$
\mathrm{E}\left(\mathrm{Y}^{\mathrm{C}} \mid \mathrm{S}=1, \mathrm{X}\right)=\mathrm{E}\left(\mathrm{Y}^{\mathrm{C}} \mid \mathrm{S}=0, \mathrm{X}\right)
$$

Based upon this equality, the outcome of the non-subsidized firms can be used to estimate the counterfactual situation of the subsidized firms and the treatment effect can then be written as:

$$
\alpha^{\mathrm{TT}}=\mathrm{E}\left(\mathrm{Y}^{\mathrm{T}} \mid \mathrm{S}=1, \mathrm{X}=\mathrm{x}\right)-\mathrm{E}\left(\mathrm{Y}^{\mathrm{C}} \mid \mathrm{S}=0, \mathrm{X}=\mathrm{x}\right)
$$

Consequently, a two-sample t-test on the matched samples can be applied to test the hypothesis whether $\alpha^{\mathrm{TT}}=0$. Usually, $\mathrm{X}$ contains many different variables in order to satisfy 
the CIA. This makes it almost impossible to find control variables that exactly fit the characteristics of the subsidized firm. In other words, the so-called curse of dimensionality occurs because the more dimensions that are included, the more difficult it becomes to find a good match. Rosenbaum and Rubin (1983) showed that it is possible to reduce $X$ to a single index, the propensity score, and match on this index instead of on all the individual $X$. The propensity scores are constructed based upon a probit regression of treatment, in this case subsidies, on the exogenous variables and then used as matching argument.

We thus implement propensity score matching, and search for the nearest neighbor in propensity scores for each treated firm in the potential control group of non-subsidized firms. As it may happen that the nearest neighbor is still quite different from a treated firm, we perform Caliper Matching (Cochran and Rubin, 1973). This method is similar to nearest neighbor matching but it adds the additional restriction that the propensity score of the nearest neighbor is within a certain, pre-specified distance. Thus, by applying this method, it is possible that a treated observation cannot be matched to a satisfactorily similar control. We further require that the matched control observations correspond to the same sample year and the same geographical region (Eastern versus Western Germany) as the treated firm observations.

As we sample with replacement in the matching routine, i.e. the same control may be used for multiple treated firms, we follow Lechner (2001) and calculate his estimator for an asymptotic approximation of the standard errors of the sample t-test on $\alpha^{\mathrm{TT}}=0$.

\section{Subsidy output evaluation: the patent production function}

Even if full crowding-out is rejected, it does not imply that public efforts lead to new technologies. ${ }^{3}$ Subsidized projects might be associated with a higher chance of failure and/or lower expected revenues than projects that the firms finance themselves even in the absence of subsidies. Therefore the subsidized projects might also have lower technological output (David et al., 2000). In addition, the additional money might be redirected to increase wages of existing staff, which may not be translated in an increase in output (unless staff becomes more productive) (Goolsbee, 1998; Howells, 2008).

In order to assess the effect of both privately and publicly funded R\&D on technolog-

\footnotetext{
${ }^{3}$ The focus in this study is only on technological performance of the subsidized firm themselves. This cannot account for any effects subsidies might have on other firms via possible spill-over effects that occur between subsidized firms and other firms in the economy.
} 
ical performance, we estimate their effects on patent applications. Patents are extensively discussed and acknowledged as an indicator of technological performance (see Pakes and Griliches, 1984; Griliches, 1990, 1998 or OECD, 1994). More specifically, they point to immediate output of the R\&D process, i.e. successful R\&D. 4

In order to estimate the patent production function, count data models are used. QMLE (Quasi-Maximum Likelihood Estimator) Poisson models are estimated in order to analyze the impact of R\&D on the number of patent applications. Using QML Poisson takes into account any form of over- or under-dispersion which would otherwise lead to incorrect standard errors (Wooldridge, 2002). In this setting, R\&D is split into two components, purely private $R \& D$ (the counterfactual situation) and publicly induced R\&D (referring to both the subsidies as well as possibly additionally induced private R\&D because of the subsidies). As these two variables cannot be directly observed, we construct them based upon the previous matching procedure by disentangling the R\&D input into the R\&D engagement of the firm in the absence of a treatment, $R \& D_{i}^{C}$, and the additionally induced $R \& D$ by the subsidy (including the subsidy itself), $\alpha_{i}^{T T}$. Note that the observed $R \& D_{i}$ is thus decomposed according to eq. 3: $R \& D_{i}=R \& D_{i}^{C}+\alpha_{i}^{T T}$. Therefore, the second equation to be estimated can be written as

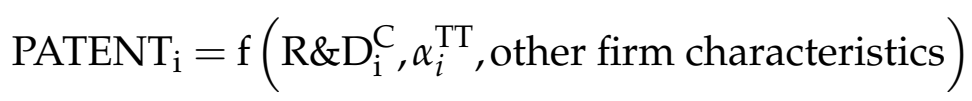

If subsidies have a positive effect on technological performance, $\alpha_{i}^{T T}$ should positively influence the patent outcome. ${ }^{5}$

Although several scholars already investigated input additionality effects, not many studies tried to establish an explicit link between a certain (government) intervention and patenting behavior. Branstetter and Sakakibara (2002) focus on the effect of being a member in a subsidized research consortium, and find that it has a positive effect on patenting. Czarnitzki et al. (2007) focus on the effect of subsidies and collaboration on patent outcome, but as an output variable in the matching routine, thus not disentangling the counterfactual and publicly induced R\&D. In line with the current study, but focusing on all types of firms in

\footnotetext{
${ }^{4}$ In spite of being a direct indicator of technological progress, patents are a narrow measure of innovation output. Other variables, like successful innovations in terms of sales with new products or cost reductions, could serve as further indicators of innovation outcome. Also employment growth as the ultimate goal of many policy initiatives would be a very interesting extension of our study. We choose patents, as they should be the closest outcome of the corresponding research projects with respect to timing.

${ }^{5}$ Note that contemporaneous R\&D is inserted in this equation as this has been found to have the strongest effect on patenting (Hall et al., 1986; Pakes and Griliches, 1984).
} 
the economy, Czarnitzki and Hussinger (2004) and Czarnitzki and Licht (2006) implement a matching estimator in order to estimate innovation input additionality and then estimate output additionality in a second step as outlined here.

\section{Data, variables and descriptive statistics}

\subsection{Data sources}

The data used in this paper stem from the Mannheim Innovation Panel (MIP), the German part of the Community Innovation Survey. Next to information on general firm-level characteristics, this database contains specific information on innovation activities and the receipt of subsidies. Our data are pooled cross-sections of the years (these years of the MIP data include information on subsidies): 1994, 1996, 1998, 2000, 2002, 2003, 2004 and 2006. Patent data are taken from the German Patent and Trade Mark Office (GPTO). Our version of the database contains information on all patent applications in Germany from 1979 to 2005. Patent and firm data were linked using a computer-supported text search algorithm and potential matches were checked manually. Furthermore, some variables have been gathered from the 'Creditreform' database. Creditreform is the largest German credit rating agency and the database includes information on firms' ratings and other variables.

Unfortunately, we can use the data only as pooled cross-sections but not as a panel: of the total sample of 3,272 observations, corresponding to 2,399 different firms, about $72 \%$ of the firms are only observed once. As a consequence, panel econometric approaches are not applicable as we would need to drop the $72 \%$ of the sampled firms that are only observed once.

Our sample includes NTBFs, Group NTBFs, LTBFs and Group LTBFs. All these firm classes have less than 250 employees and are less than 10 years old. ${ }^{6}$ NTBFs and Group NTBFs belong to the high-tech or key-tech technologies as defined in the high-tech strategy

\footnotetext{
${ }^{6}$ In general, literature is ambiguous in defining NTBFs and small, young firms in general. With respect to size, the threshold of 250 employees is the official threshold of SME's, while small firms in the strict sense are officially defined (as e.g. by the European Commission) as having less than 50 employees. In literature, either one of the thresholds is used to define small firms (Schneider and Veugelers, 2010; Acs and Audretsch, 1989). With respect to age, literature is even more ambiguous when it comes to determining 'young' age. (Colombo et al., 2012, 2011; Grilli and Murtinu, 2012). In order to test whether our results are robust to alternative criteria, we also conducted the matching estimation for firms having less than 50 employees and being less than 5 years old. The differences found between the different firm categories are robust. However, with the more restrictive definition we run into small sample size problems for the second step of the analysis, the estimation of output effects.
} 
(BMBF (Federal Ministry of Education and Research), 2010), while LTBFs and Group LTBFs belong to medium low-tech and low-tech sectors (for an overview of the industry classification, see table A1 in appendix). ${ }^{7}$ In addition, all the firms in the sample are innovative and have thus introduced at least one new or significantly improved product or process, or have ongoing or abandoned innovation projects during the period covered in the survey.

Table 2 presents the sizes of the different samples before and after matching. As can be derived from the table, the sample initially consists of 1228 NTBFs, 609 Group NTBFs, 965 LTBFs and 470 Group LTBFs in total. Among those, the non-subsidized firms can potentially serve as controls for matching. Table 2 shows that, in line with expectations, a larger share of NTBFs receive subsidies than LTBFs. The table also shows how many of the treated observations could be matched to nearest neighbors that were similar enough in observed characteristics. For instance, out of 649 subsidized NTBFs, a close neighbor could be found for 599.

\subsection{Variables}

\subsubsection{Dependent variables}

This study investigates the influence of subsidies on various outcome variables. The receipt of subsidies is denoted by a dummy variable SUB, and covers subsidies from the national or regional governments and from the EU. In order to evaluate the effect of subsidies on the innovative behavior of firms, we investigate the impact on R\&D intensity of these firms, RDint. This variable is constructed as the ratio of internal R\&D expenditures to turnover (multiplied by 100). We also evaluate the subsidy effect on the level of R\&D expenditures (R\&D).

A large part of R\&D spending consists of salaries of R\&D employees. If companies increase their R\&D expenditures after receiving R\&D subsidies, a large fraction of this increased spending might be due to hiring new R\&D employees. However, as Goolsbee (1998) states, R\&D labor supply might be quite inelastic and the increased spending might instead be redirected to higher wages for existing staff instead of resulting in new human capital which is not the direct aim of government subsidies. If it would be the case that R\&D sub-

\footnotetext{
${ }^{7}$ Note that this distinction between high-tech and low-tech industries also coincides with distinguishing between the most and least R\&D intensive sectors in the German economy based upon the survey data.
} 
Table 2: Numbers of observations in the different subsamples

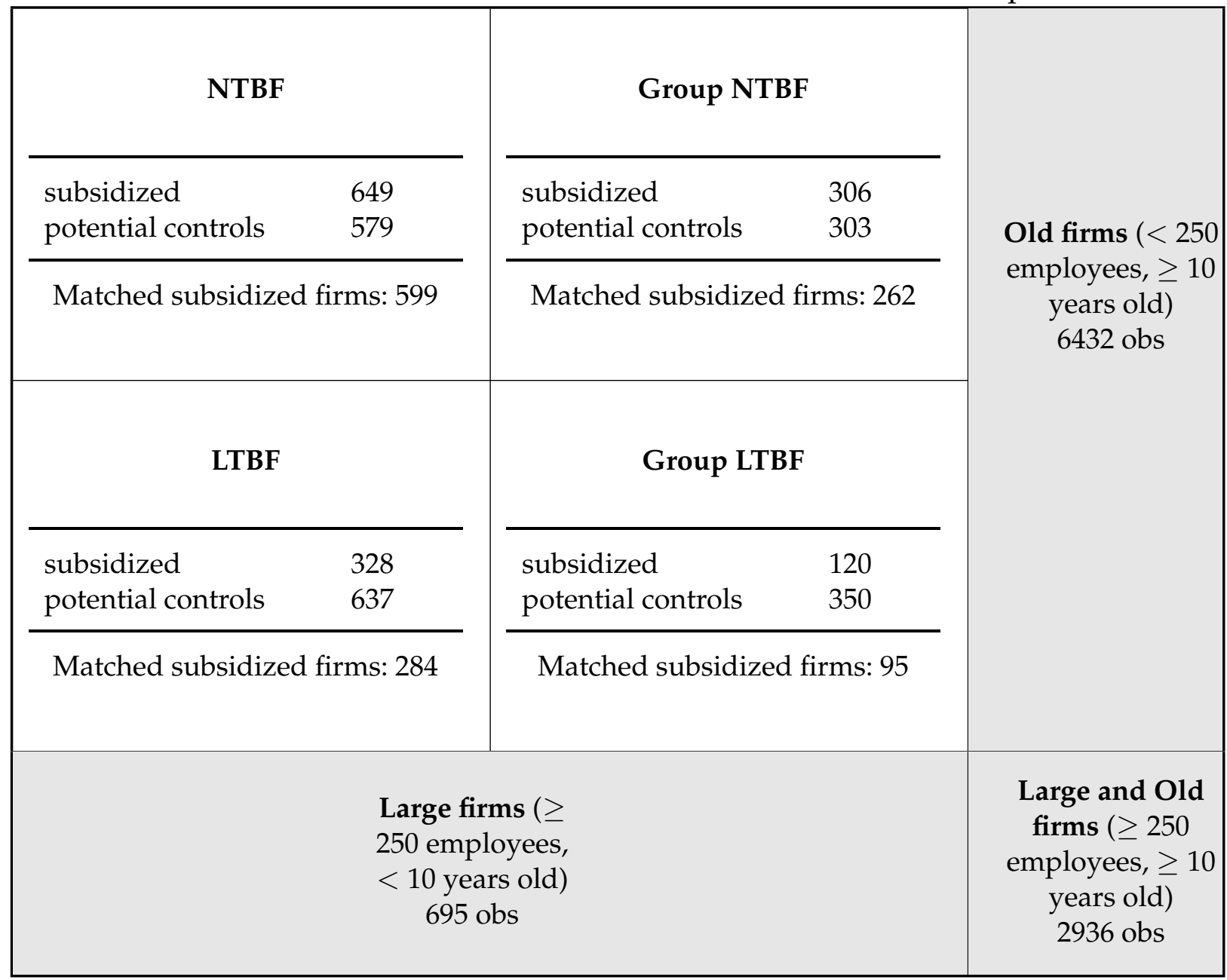

sidies lead to higher wages, a positive treatment effect found for R\&D spending might thus not mean that more knowledge is created in the economy. Only if either new R\&D staff is hired or higher wages lead to higher R\&D productivity, the policy would have its desired effects. Therefore, we first test whether not only R\&D spending is related positively to the subsidy receipt but also R\&D employment. We use two variables, the number of R\&D employees (RDemp) and the R\&D employment intensity (RDEint) measured as the number of R\&D employees over the total number of employees (multiplied by 100).

In order to investigate the effect of subsidies on output, we disentangle RDEint into the counterfactual situation $R D E i n t_{i}^{C}$ and the additionally induced R\&D employment intensity, $\alpha_{T T, i}$ for all four firm groups. The dependent variable in this stage is the number of patent applications (PAT). Note that this output stage also takes into account R\&D productivity boosts because of potentially increased wages of R\&D personnel. 


\subsubsection{Explanatory variables}

Although we focus on SMEs, there might still be differences between the larger and smaller firms within this subset. Therefore, we control for firm size by the log of total employment, $\ln (\mathrm{EMP})$, and also its square, $(\ln (\mathrm{EMP}))^{2}$, in order to capture possible nonlinearities. Similarly, although we are already focusing on the youngest firms in the economy, we include the logarithm of age $(\ln (\mathrm{AGE}))$ in the analysis in order to capture differences between younger and older firms.

Firms that export to other countries might be more innovative than other companies. The chance that they apply for innovation subsidies is thus also higher. As a consequence, a dummy indicating whether a firm is an exporter or not, EXPORTER, is included in the analysis. Another variable that may be correlated with subsidy receipt is capital intensity (CAPINT), measured as (fixed assets/EMP). Capital intensive firms supposedly rely more heavily on innovation activities than the less capital intensive ones.

Another variable that is included is the price-cost margin (PCM). Firms with a higher price-cost margin are more likely to have financial resources for internal funding of $R \& D$ projects. As a consequence, they might apply less for subsidies. However, a high price-cost margin might be the result of successful past innovation activities and the likelihood to receive subsidies might thus increase. The price-cost margin is constructed as suggested by Collins and Preston (1969) and Ravenscraft (1983): ((sales - staff cost - material costs)/ sales).

The history of (successful) R\&D activities is likely to strongly influence both the probability to receive subsidies, $R \& D$ expenditures and $R \& D$ employment. If a firm already has a lot of experience in R\&D activities, this firm is more likely to know how to apply for subsidies and to invest more in new R\&D activities. In addition, governments often adopt a pickingthe-winner strategy and firms with previous successful innovations might thus be favored in the granting process. In order to capture the influence of past $R \& D$, we include the patent stock in our regression as patent stock per employee (PS/EMP). We divide by employees in order to reduce potential multicollinearity with firm size. Patent stock is defined as

$$
\mathrm{PS}_{i t}=(1-\delta) \mathrm{PS}_{i, t-1}+\mathrm{PA}_{i t}
$$

where PS is the patent stock of firm $i$ in period $t$ and $t-1$ respectively, PA is the number of patent applications filed in period $t$. The patent stock in period $t-1$ is depreciated at a 
constant rate, with $\delta$ set to 0.15 (see e.g. Jaffe, 1986; Hall, 1990; Griliches and Mairesse, 1984).

As already elaborated, credit constraints might also have an influence on subsidy receipt and the outcome variables. In order to capture the access a firm has to external capital, we use the firm's credit rating, RATING, lagged one period. The rating is an index ranging from 100 to 600 , where 600 is the worst and essentially corresponds to bankruptcy of the firm.

The dummy variable EAST indicates firms that are located in Eastern Germany. Eastern Germany is still in transition from a planned to a market economy, and firm behavior may thus be different. In addition, Eastern German firms are preferred in the policy incentive schemes, and special schemes have been launched exclusively for these firms in order to accelerate the catching up process in this region.

In addition, we control for differences in technological opportunities with industry dummies (see Table A1 in the appendix for details). These industry dummies are based on the NACE codes, the European industry standard classification system. Finally, seven time dummies control for business cycle effects.

For the variables PCM, CAPINT and RATING, we have some missing values. In order to account for these missing values, we construct dummy variables equal to 1 if the values are missing (D(PCM), D(CAPINT) and $\mathrm{D}($ RATING)). In addition, we set the missing values in the original variables to zero. Including both the dummy variable and the adjusted original variables in the analysis corrects for missing values and avoids the imputation of unknown values.

Also note that all time-varying variables (except AGE) enter the regression as lagged values to avoid simultaneity bias.

\subsection{Descriptive statistics}

Table 3 displays the descriptive statistics of the variables used for the four different firm types. The t-tests reveal that there are some significant differences between subsidized firms and the potential control groups. The subsidized firms are, on average, more export-oriented, are more often situated in Eastern Germany and have more patents per employee. Some average differences are only significant for specific firm types. For example, only the independent subsidized firms have, on average, significant more employees than the non-subsidized independent firms. Similarly, only the class of high-tech subsidized firms has, on average, a significant lower price cost margin than the non-subsidized class and only the independent 
high-tech firms have a lower credit rating (thus higher values of the RATING variable) for subsidized firms than for the potential control group.

Table 3: Descriptive statistics ${ }^{a}$

\begin{tabular}{|c|c|c|c|c|c|c|c|c|c|c|}
\hline & \multicolumn{2}{|c|}{$\begin{array}{c}\text { subsidized firms } \\
N_{1}=649\end{array}$} & \multicolumn{2}{|c|}{$\begin{array}{l}\text { NTBFs } \\
\text { potential control group } \\
\quad N_{1}=579\end{array}$} & \multirow{2}{*}{$\begin{array}{l}\mathrm{p} \text {-value of two- } \\
\text { sided t-test on } \\
\text { mean equality }\end{array}$} & \multicolumn{2}{|c|}{$\begin{array}{c}\text { subsidized firms } \\
N_{1}=306\end{array}$} & \multicolumn{2}{|c|}{$\begin{array}{l}\text { Group NTBFs } \\
\text { potential control group } \\
\qquad N_{1}=303\end{array}$} & \multirow{2}{*}{$\begin{array}{l}\mathrm{p} \text {-value of two- } \\
\text { sided } \mathrm{t} \text {-test on } \\
\text { mean equality }\end{array}$} \\
\hline & Mean & Std. Dev. & Mean & Std. Dev. & & Mean & Std. Dev. & Mean & Std. Dev. & \\
\hline EMP & 42.515 & 52.871 & 36.546 & 48.737 & $\mathrm{p}=0.041$ & 80.330 & 72.048 & 90.185 & 159.540 & $\mathrm{p}=0.326$ \\
\hline AGE & 6.131 & 2.034 & 6.195 & 2.112 & $\mathrm{p}=0.588$ & 6.075 & 2.086 & 6.092 & 2.129 & $\mathrm{p}=0.920$ \\
\hline EXPORTER & 0.629 & 0.484 & 0.390 & 0.488 & $\mathrm{p}<0.0001$ & 0.752 & 0.433 & 0.581 & 0.494 & $\mathrm{p}<0.0001$ \\
\hline CAPINT* & 0.064 & 0.110 & 0.129 & 1.261 & $\mathrm{p}=0.290$ & 0.238 & 1.644 & 0.064 & 0.103 & $\mathrm{p}=0.174$ \\
\hline $\mathrm{PCM}^{*}$ & 0.032 & 0.950 & 0.226 & 0.622 & $\mathrm{p}=0.001$ & 0.044 & 0.673 & 0.186 & 0.778 & $\mathrm{p}=0.042$ \\
\hline EAST & 0.678 & 0.468 & 0.427 & 0.495 & $\mathrm{p}<0.0001$ & 0.663 & 0.473 & 0.294 & 0.456 & $\mathrm{p}<0.0001$ \\
\hline PS/EMP & 0.040 & 0.078 & 0.013 & 0.045 & $\mathrm{p}<0.0001$ & 0.038 & 0.069 & 0.019 & 0.052 & $\mathrm{p}<0.0001$ \\
\hline RATING* & 251.777 & 55.770 & 243.727 & 49.940 & $\mathrm{p}=0.011$ & 238.257 & 39.115 & 235.948 & 37.201 & $\mathrm{p}=0.489$ \\
\hline D(CAPINT) & 0.337 & 0.473 & 0.509 & 0.500 & $\mathrm{p}=0.000$ & 0.255 & 0.437 & 0.452 & 0.499 & $\mathrm{p}=0.000$ \\
\hline $\mathrm{D}(\mathrm{PCM})$ & 0.250 & 0.433 & 0.444 & 0.497 & $\mathrm{p}=0.000$ & 0.209 & 0.407 & 0.376 & 0.485 & $\mathrm{p}=0.000$ \\
\hline D(RATING) & 0.074 & 0.262 & 0.090 & 0.286 & $\mathrm{p}=0.311$ & 0.098 & 0.298 & 0.175 & 0.381 & $\mathrm{p}=0.006$ \\
\hline$\hat{P}(X)$ & 0.635 & 0.209 & 0.408 & 0.203 & $\mathrm{p}<0.0001$ & 0.628 & 0.222 & 0.376 & 0.211 & $\mathrm{p}<0.0001$ \\
\hline RDint & 19.573 & 29.217 & 3.568 & 11.419 & $\mathrm{p}<0.0001$ & 16.808 & 28.774 & 4.510 & 15.550 & $\mathrm{p}<0.0001$ \\
\hline RDEint & 32.568 & 29.865 & 9.639 & 18.113 & $\mathrm{p}<0.0001$ & 25.734 & 27.599 & 9.082 & 18.382 & $\mathrm{p}<0.0001$ \\
\hline R\&D & 1.013 & 4.945 & 0.147 & 0.579 & $\mathrm{p}<0.0001$ & 1.804 & 4.770 & 0.868 & 2.515 & $\mathrm{p}=0.003$ \\
\hline R\&Demp & 8.957 & 14.786 & 1.875 & 3.913 & $\mathrm{p}<0.0001$ & 15.779 & 25.637 & 6.344 & 17.444 & $\mathrm{p}<0.0001$ \\
\hline \multirow[t]{3}{*}{$\mathrm{PAT}^{b}$} & 0.444 & 1.253 & 0.128 & 1.224 & $\mathrm{p}<0.0001$ & 0.682 & 1.805 & 0.244 & 1.191 & $\mathrm{p}<0.0001$ \\
\hline & \multicolumn{2}{|c|}{$\begin{array}{c}\text { subsidized firms } \\
N_{1}=328\end{array}$} & \multicolumn{2}{|c|}{$\begin{array}{l}\text { Low-Tech NTBFs } \\
\text { potential control group } \\
\qquad N_{1}=637\end{array}$} & \multirow{2}{*}{$\begin{array}{l}\text { p-value of two- } \\
\text { sided t-test on } \\
\text { mean equality }\end{array}$} & \multicolumn{2}{|c|}{$\begin{array}{c}\text { subsidized firms } \\
N_{1}=120\end{array}$} & \multicolumn{2}{|c|}{$\begin{array}{l}\text { Low-Tech Group NTBFs } \\
\text { potential control group } \\
\qquad N_{1}=350\end{array}$} & \multirow{2}{*}{$\begin{array}{l}\mathrm{p} \text {-value of two- } \\
\text { sided } \mathrm{t} \text {-test on } \\
\text { mean equality }\end{array}$} \\
\hline & Mean & Std. Dev. & Mean & Std. Dev. & & Mean & Std. Dev. & Mean & Std. Dev. & \\
\hline EMP & 57.845 & 55.165 & 43.848 & 46.898 & $\mathrm{p}<0.0001$ & 87.533 & 62.246 & 78.140 & 68.088 & $\mathrm{p}=0.183$ \\
\hline AGE & 6.290 & 2.133 & 6.055 & 2.118 & $\mathrm{p}=0.104$ & 6.400 & 2.056 & 6.040 & 2.162 & $\mathrm{p}=0.112$ \\
\hline EXPORTER & 0.506 & 0.501 & 0.273 & 0.446 & $\mathrm{p}<0.0001$ & 0.567 & 0.498 & 0.423 & 0.495 & $\mathrm{p}=0.006$ \\
\hline CAPINT* & 0.104 & 0.165 & 0.106 & 0.176 & $\mathrm{p}=0.914$ & 0.131 & 0.402 & 0.299 & 0.926 & $\mathrm{p}=0.100$ \\
\hline $\mathrm{PCM}^{*}$ & 0.138 & 0.696 & 0.210 & 0.686 & $\mathrm{p}=0.200$ & 0.147 & 0.676 & 0.207 & 0.858 & $\mathrm{p}=0.549$ \\
\hline EAST & 0.872 & 0.335 & 0.641 & 0.480 & $\mathrm{p}<0.0001$ & 0.742 & 0.440 & 0.414 & 0.493 & $\mathrm{p}<0.0001$ \\
\hline PS/EMP & 0.015 & 0.054 & 0.004 & 0.025 & $\mathrm{p}<0.0001$ & 0.016 & 0.051 & 0.003 & 0.017 & $\mathrm{p}<0.0001$ \\
\hline RATING* & 244.379 & 38.679 & 245.960 & 54.059 & $\mathrm{p}=0.653$ & 232.290 & 29.518 & 236.263 & 55.912 & $\mathrm{p}=0.484$ \\
\hline D(CAPINT) & 0.293 & 0.456 & 0.540 & 0.499 & $\mathrm{p}=0.000$ & 0.242 & 0.430 & 0.491 & 0.501 & $\mathrm{p}=0.000$ \\
\hline $\mathrm{D}(\mathrm{PCM})$ & 0.195 & 0.397 & 0.462 & 0.499 & $\mathrm{p}=0.000$ & 0.217 & 0.414 & 0.446 & 0.498 & $\mathrm{p}=0.000$ \\
\hline D(RATING) & 0.082 & 0.275 & 0.104 & 0.305 & $\mathrm{p}=0.289$ & 0.108 & 0.312 & 0.157 & 0.364 & $\mathrm{p}=0.190$ \\
\hline$\hat{P}(\mathrm{X})$ & 0.506 & 0.224 & 0.256 & 0.188 & $\mathrm{p}<0.0001$ & 0.426 & 0.224 & 0.200 & 0.161 & $\mathrm{p}<0.0001$ \\
\hline RDint & 4.620 & 11.313 & 0.668 & 1.625 & $\mathrm{p}<0.0001$ & 3.492 & 6.903 & 1.178 & 5.226 & $\mathrm{p}<0.0001$ \\
\hline RDEint & 11.232 & 17.374 & 3.693 & 10.809 & $\mathrm{p}<0.0001$ & 6.894 & 12.046 & 3.439 & 9.309 & $\mathrm{p}=0.001$ \\
\hline R\&D & 0.195 & 0.348 & 0.074 & 0.634 & $\mathrm{p}=0.001$ & 0.471 & 1.028 & 0.224 & 1.144 & $\mathrm{p}=0.036$ \\
\hline R\&Demp & 3.768 & 5.796 & 1.001 & 2.513 & $\mathrm{p}<0.0001$ & 3.938 & 5.851 & 1.797 & 6.135 & $\mathrm{p}=0.001$ \\
\hline $\mathrm{PAT}^{b}$ & 0.121 & 0.528 & 0.029 & 0.227 & $\mathrm{p}<0.0001$ & 0.581 & 2.372 & 0.120 & 1.120 & $\mathrm{p}=0.006$ \\
\hline
\end{tabular}

With respect to the outcome variables, the NTBFs and Group NTBFs show the highest values in general. In addition, all outcome variables differ significantly between subsidized firms and their respective control groups. In all cases, the subsidized firms have higher intensities and more R\&D expenditures and employees. The question whether these differences can be attributed to the subsidies will be empirically investigated subsequently. 


\section{Estimation and results}

\subsection{Subsidy effect on small young firms}

In order to apply the matching estimator, we first estimate a probit model on the receipt of subsidies for obtaining propensity scores. Table 4 presents the results of this estimation in columns 2, 3, 4 and 5 of this table for the different firm categories. The first column estimates the likelihood of receiving subsidies for the full sample, introducing the different firm class dummies, with NTBF as reference category, in the estimation. This reveals that NTBFs are more likely to receive subsidies than all other firm categories defined. In addition, when testing the equality of the coefficients of the other firm categories, we find that high-tech firms in general are more likely to receive subsidies. Within each broader group of high-tech and low-tech firms, the independent ones also seem to be more likely to receive subsidies.

In addition, we find that companies located in Eastern Germany have a higher probability to receive subsidies. In addition, the results also confirm the higher probability of receiving subsidies if the patent stock is larger. Except for Group LTBFs, being an exporter has a positive effect on subsidy receipt.

Having obtained a propensity score based on the estimation results of the probit estimation on subsidy receipt, we restrict the sample to common support. The matching estimator is not appropriate for regions of the distribution where the propensity scores of the samples of treated and controls do not overlap. Table 5 shows how many observations have to be dropped for each firm class in order to assure a sufficient overlap between the treated and untreated firms under consideration. Next to the restriction of common support, we also impose a similarity threshold as we apply caliper matching. This caliper threshold defines the tolerated maximum distance between treated and untreated firms. We chose a threshold of 0.05 . The third column of table 5 presents the number of observations that are lost after setting this threshold. The last column of that table shows how many treated observations can be successfully matched.

After setting the different thresholds, we pick the nearest neighbor from the control group. After matching, there are no statistically significant differences in the exogenous variables anymore. In line with this, the propensity score is also not significantly different between the two groups (results not shown here). Table 6 shows the outcome of the tests on overall model significance of the probit models on subsidy receipt after matching as a test on 
Table 4: Probit estimation on subsidy (SUB)

\begin{tabular}{|c|c|c|c|c|c|}
\hline & $\begin{array}{c}(1) \\
\text { full sample }\end{array}$ & $\begin{array}{c}(2) \\
\text { NTBF }\end{array}$ & $\begin{array}{c}(3) \\
\text { Group NTBF }\end{array}$ & $\begin{array}{c}(4) \\
\mathrm{LTBF}\end{array}$ & $\begin{array}{c}(5) \\
\text { Group LTBF }\end{array}$ \\
\hline $\ln (\mathrm{AGE})$ & $\begin{array}{l}-0.077 \\
(0.064)\end{array}$ & $\begin{array}{l}-0.104 \\
(0.102)\end{array}$ & $\begin{array}{c}-0.264^{*} \\
(0.136)\end{array}$ & $\begin{array}{c}-0.135 \\
(0.118)\end{array}$ & $\begin{array}{c}0.215 \\
(0.184)\end{array}$ \\
\hline EXPORTER & $\begin{array}{c}0.408^{* * *} \\
(0.059)\end{array}$ & $\begin{array}{c}0.543^{* * *} \\
(0.090)\end{array}$ & $\begin{array}{l}0.420^{* * *} \\
(0.139)\end{array}$ & $\begin{array}{c}0.397^{* * *} \\
(0.107)\end{array}$ & $\begin{array}{l}-0.028 \\
(0.168)\end{array}$ \\
\hline $\ln (\mathrm{EMP})$ & $\begin{array}{c}0.045 \\
(0.116)\end{array}$ & $\begin{array}{c}0.041 \\
(0.164)\end{array}$ & $\begin{array}{l}-0.059 \\
(0.249)\end{array}$ & $\begin{array}{c}0.026 \\
(0.231)\end{array}$ & $\begin{array}{c}0.329 \\
(0.361)\end{array}$ \\
\hline $\ln (\mathrm{EMP}) 2$ & $\begin{array}{l}-0.000 \\
(0.017)\end{array}$ & $\begin{array}{c}0.001 \\
(0.025)\end{array}$ & $\begin{array}{c}0.000 \\
(0.034)\end{array}$ & $\begin{array}{c}0.016 \\
(0.034)\end{array}$ & $\begin{array}{l}-0.036 \\
(0.050)\end{array}$ \\
\hline D(CAPINT) & $\begin{array}{c}-0.273^{* * *} \\
(0.092)\end{array}$ & $\begin{array}{l}-0.163 \\
(0.139)\end{array}$ & $\begin{array}{l}-0.226 \\
(0.218)\end{array}$ & $\begin{array}{l}-0.303^{*} \\
(0.181)\end{array}$ & $\begin{array}{l}-0.416 \\
(0.285)\end{array}$ \\
\hline CAPINT & $\begin{array}{l}-0.008 \\
(0.036)\end{array}$ & $\begin{array}{l}-0.126 \\
(0.343)\end{array}$ & $\begin{array}{c}0.836 \\
(0.750)\end{array}$ & $\begin{array}{c}0.400 \\
(0.353)\end{array}$ & $\begin{array}{l}-0.179 \\
(0.174)\end{array}$ \\
\hline PCM & $\begin{array}{l}-0.091 \\
(0.056)\end{array}$ & $\begin{array}{l}-0.134^{*} \\
(0.074)\end{array}$ & $\begin{array}{l}-0.138 \\
(0.088)\end{array}$ & $\begin{array}{c}0.005 \\
(0.085)\end{array}$ & $\begin{array}{l}-0.074 \\
(0.107)\end{array}$ \\
\hline $\mathrm{D}(\mathrm{PCM})$ & $\begin{array}{c}-0.186^{* *} \\
(0.093)\end{array}$ & $\begin{array}{l}-0.223 \\
(0.140)\end{array}$ & $\begin{array}{l}-0.122 \\
(0.204)\end{array}$ & $\begin{array}{c}-0.375^{* *} \\
(0.190)\end{array}$ & $\begin{array}{c}0.124 \\
(0.280)\end{array}$ \\
\hline EAST & $\begin{array}{c}0.958^{* * *} \\
(0.065)\end{array}$ & $\begin{array}{c}0.989^{* * *} \\
(0.091)\end{array}$ & $\begin{array}{l}1.094^{* * *} \\
(0.120)\end{array}$ & $\begin{array}{c}1.053^{* * *} \\
(0.127)\end{array}$ & $\begin{array}{c}0.966^{* * *} \\
(0.164)\end{array}$ \\
\hline PS/EMP & $\begin{array}{c}3.831^{* * *} \\
(0.587)\end{array}$ & $\begin{array}{c}3.310^{* * *} \\
(0.692)\end{array}$ & $\begin{array}{c}3.301^{* * *} \\
(1.020)\end{array}$ & $\begin{array}{c}5.365^{* * *} \\
(1.349)\end{array}$ & $\begin{array}{c}8.982^{* * *} \\
(2.744)\end{array}$ \\
\hline RATING & $\begin{array}{l}-0.000 \\
(0.001)\end{array}$ & $\begin{array}{c}0.000 \\
(0.001)\end{array}$ & $\begin{array}{l}-0.001 \\
(0.002)\end{array}$ & $\begin{array}{l}-0.002^{*} \\
(0.001)\end{array}$ & $\begin{array}{l}-0.002 \\
(0.002)\end{array}$ \\
\hline D(RATING) & $\begin{array}{c}-0.205 \\
(0.169)\end{array}$ & $\begin{array}{c}0.184 \\
(0.244)\end{array}$ & $\begin{array}{c}-0.623 \\
(0.446)\end{array}$ & $\begin{array}{c}-0.436 \\
(0.316)\end{array}$ & $\begin{array}{l}-0.555 \\
(0.539)\end{array}$ \\
\hline GroupNTBF & $\begin{array}{c}-0.177^{* *} \\
(0.080)\end{array}$ & & & & \\
\hline LTBF & $\begin{array}{c}-0.457^{* * *} \\
(0.166)\end{array}$ & & & & \\
\hline GroupLTBF & $\begin{array}{c}-0.641^{* * *} \\
(0.170)\end{array}$ & & & & \\
\hline Constant & $\begin{array}{l}-0.286 \\
(0.303)\end{array}$ & $\begin{array}{l}-0.119 \\
(0.402)\end{array}$ & $\begin{array}{l}-0.122 \\
(0.716)\end{array}$ & $\begin{array}{l}-0.534 \\
(0.677)\end{array}$ & $\begin{array}{c}-3.075^{* *} \\
(1.201)\end{array}$ \\
\hline $\begin{array}{l}\text { Test on joint significance of } \\
\text {-industry dummies } \\
\text {-time dummies } \\
\text { test: GNTBF = LTBF = GLTBF } \\
\text { test: GNTBF = LTBF } \\
\text { test: GNTBF = GLTBF } \\
\text { test: } \mathrm{LTBF}=\text { GLTBF }\end{array}$ & $\begin{array}{c}\chi^{2}(11)=37.71^{* * *} \\
\chi^{2}(7)=46.08^{* * *} \\
\chi^{2}(2)=9.45^{* * *} \\
\chi^{2}(1)=2.73^{*} \\
\chi^{2}(1)=7.38^{* * *} \\
\chi^{2}(1)=4.36^{* *}\end{array}$ & $\begin{array}{c}\chi^{2}(4)=6.63 \\
\chi^{2}(7)=48.92^{* * *}\end{array}$ & $\begin{array}{l}\chi^{2}(4)=7.34 \\
\chi^{2}(7)=4.35\end{array}$ & $\begin{array}{l}\chi^{2}(8)=25.26^{* * *} \\
\chi^{2}(7)=23.60^{* * *}\end{array}$ & $\begin{array}{l}\chi^{2}(8)=11.38 \\
\chi^{2}(7)=9.02\end{array}$ \\
\hline $\begin{array}{l}N \\
\text { Log-Likelihood } \\
\text { Pseudo } R^{2}\end{array}$ & $\begin{array}{c}3272 \\
-1786.094 \\
0.20\end{array}$ & $\begin{array}{c}1228 \\
-694.532 \\
0.18\end{array}$ & $\begin{array}{c}609 \\
-336.673 \\
0.20\end{array}$ & $\begin{array}{c}965 \\
-490.595 \\
0.21\end{array}$ & $\begin{array}{c}470 \\
-212.636 \\
0.20\end{array}$ \\
\hline
\end{tabular}

Standard errors in parentheses

${ }^{*} \mathrm{p}<0.10,{ }^{* *} \mathrm{p}<0.05,{ }^{* * *} \mathrm{p}<0.01$ 
Table 5: Loss of subsidized observations due to a lack of common support and due to caliper threshold

\begin{tabular}{llllll}
\hline sample & $\begin{array}{l}\text { Initial sample } \\
\text { size of subsidized } \\
\text { firms }\end{array}$ & $\begin{array}{l}\text { lack of common } \\
\text { support }\end{array}$ & $\begin{array}{l}\text { out of caliper final sample size } \\
\text { threshold } 0.05\end{array}$ & $\begin{array}{l}\text { firms } \\
\text { of subsidized }\end{array}$ \\
\hline NTBF & 649 & -4 & -46 & 599 \\
Group NTBF & 306 & -4 & -40 & 262 \\
LTBF & 328 & -8 & -36 & 284 \\
Group LTBF & 120 & -8 & -17 & 95 \\
\hline
\end{tabular}

the quality of the matching routine. As can be seen in the table, the null hypothesis that all coefficients in the regressions are jointly zero is not rejected for any type of firm, as expected in case of successful matching.

Table 6: Significance of probit regressions after matching

\begin{tabular}{llll}
\hline sample & \# obs & Wald $\chi^{2(23)}$ & p-value \\
\hline NTBFs & 1198 & 5.17 & 1.0000 \\
Group NTBFs & 524 & 8.76 & 0.9967 \\
Low-tech NTBFs & 568 & $16.87^{a}$ & 0.9342 \\
Group low-tech NTBFs & 190 & $15.99^{a}$ & 0.9531 \\
\hline
\end{tabular}

${ }^{a}$ : Due to different industry classification of low-tech NTBFs: Wald $\chi^{2(27)}$

Table 7 presents the matching results concerning the outcome variables. Almost all treatment effects are positive and significant, which can, after matching, be attributed to the receipt of subsidies. As a consequence, full crowding-out effects are rejected for all firm types. However, the table also suggests that the treatment effects may differ across the different firm categories. In order to analyze the heterogeneity in treatment effects in more detail, we apply an auxiliary regression analysis in the following subsection.

\subsection{Further evaluation of the treatment effects}

In order to investigate possible heterogeneity across firm types in more detail, we obtain $\alpha_{\mathrm{TT}, \mathrm{i}}$ for each treated firm from the matching routine. As we are interested in testing whether the effects differ across firm types, we run the following supplemental regression after the matching where we pool the four samples of different firm types. 
Table 7: Treatment effects after matching

\begin{tabular}{|c|c|c|c|c|}
\hline \multicolumn{2}{|c|}{ NTBF } & \multicolumn{2}{|c|}{ Group NTBF } & \multirow{12}{*}{ Small Old firms } \\
\hline \multicolumn{2}{|c|}{ Matched subsidized firms: 599} & \multicolumn{2}{|c|}{ Matched subsidized firms: 262} & \\
\hline R\&Dint & $14.103^{* * *}$ & R\&Dint & $8.292^{* *}$ & \\
\hline R\&DEint & $20.555^{* * *}$ & R\&DEint & $11.840^{* * *}$ & \\
\hline $\mathrm{R} \& \mathrm{D}$ & $0.702^{* * *}$ & $\mathrm{R} \& \mathrm{D}$ & 0.344 & \\
\hline R\&D emp & $5.241^{* * *}$ & R\&D emp & $7.167^{* * *}$ & \\
\hline \multicolumn{2}{|c|}{ LTBF } & \multicolumn{2}{|c|}{ Group LTBF } & \\
\hline \multicolumn{2}{|c|}{ Matched subsidized firms: 284} & \multicolumn{2}{|c|}{ Matched subsidized firms: 95} & \\
\hline R\&Dint & $3.132^{* * *}$ & R\&Dint & $1.628^{*}$ & \\
\hline R\&DEint & $3.901^{* *}$ & R\&DEint & $3.934^{* * *}$ & \\
\hline $\mathrm{R} \& \mathrm{D}$ & $0.094^{* * *}$ & $\mathrm{R} \& \mathrm{D}$ & $0.205^{* *}$ & \\
\hline R\&D emp & $1.630^{* * *}$ & R\&D emp & $1.897^{* *}$ & \\
\hline \multicolumn{4}{|c|}{$\begin{array}{l}\text { Large young } \\
\text { firms }\end{array}$} & Large old firms \\
\hline
\end{tabular}

$$
\alpha_{\mathrm{TT}, \mathrm{i}}=\beta_{0}+\beta_{1} \text { GroupNTBF }_{\mathrm{i}}+\beta_{2} \mathrm{LTBF}_{\mathrm{i}}+\beta_{3} \operatorname{GroupLTBF}_{\mathrm{i}}+\epsilon_{\mathrm{i}}
$$

The constant term $\beta_{0}$ then reflects the treatment effect for NTBFs and the other coefficients show the difference in treatment effects relative to NTBFs. In order to evaluate the differences of the treatment effects with respect to other firm types, we perform F-tests on the equality of their coefficients.

While simply regressing the treatment effect on the different firm type dummies indicates to what extent the differences in treatment effects are significant, this does not account for other factors that might influence these differences. In order to control for other effects, we include extra control variables, $X_{i}$, in the regressions on the treatment effects.

$$
\alpha_{\mathrm{TT}, \mathrm{i}}=\beta_{0}+\beta_{1} \text { GroupNTBF }_{\mathrm{i}}+\beta_{2} \mathrm{LTBF}_{\mathrm{i}}+\beta_{3} \text { GroupLTBF }_{\mathrm{i}}+\beta_{\mathrm{X}} \mathrm{X}_{\mathrm{i}}+\epsilon_{\mathrm{i}}
$$

As already shown above, young high-tech SMEs seem to be more likely to receive sub- 
sidies. If these firms thus get funding from multiple sources, it might actually explain why they seem to have higher treatment effects than low-tech firms. All firms included in the estimation of the treatment effect are subsidized firms, having received funding from at least one source. However, it is possible that some firms included in the sample received subsidies from both the European Union, the federal government and local governments. Similarly, some firms might have been subsidized by two different funding sources. Czarnitzki and Lopes Bento (2014) differentiate between firms having received national funding, European funding and funding at both the national and the European level and find that, in terms of input, getting funding from both sources yields the highest impact. As a consequence, we control for these multiple sources of subsidies. We do so by including two dummies 2SUB and 3SUB, referring to firms that received subsidies from 2 funding sources and all 3 funding sources respectively; firms that received funding from only one source are the reference category.

Another factor, very specific to the German case is the difference between Eastern and Western Germany. Czarnitzki and Licht (2006) found that input additionality has been more pronounced in Eastern Germany during the transition period than in Western Germany. In addition, Eastern German firms were preferred in several subsidy schemes in order to accelerate the transition process after the German re-unification in 1991. It is thus possible that the differences in treatment effects between different firm types can be attributed to the fact that the firm type with higher treatment effects is mainly present in Eastern Germany. In order to control for potential different location effects, we include a dummy EAST in the regressions.

Although we already focus on SMEs, we still control for heterogeneity in total employment. Next to controlling for size, we also control for age by including age in the estimation. Finally, we include time dummies in the estimation in order to control for business cycle effects. The patent stock per employee controls for heterogeneity in past R\&D success. ${ }^{8}$

\footnotetext{
${ }^{8}$ Information on the different subsidy sources is not available for all years in the analysis. As a consequence, we had to drop one year (1996) because of missing information on the subsidy sources.
} 


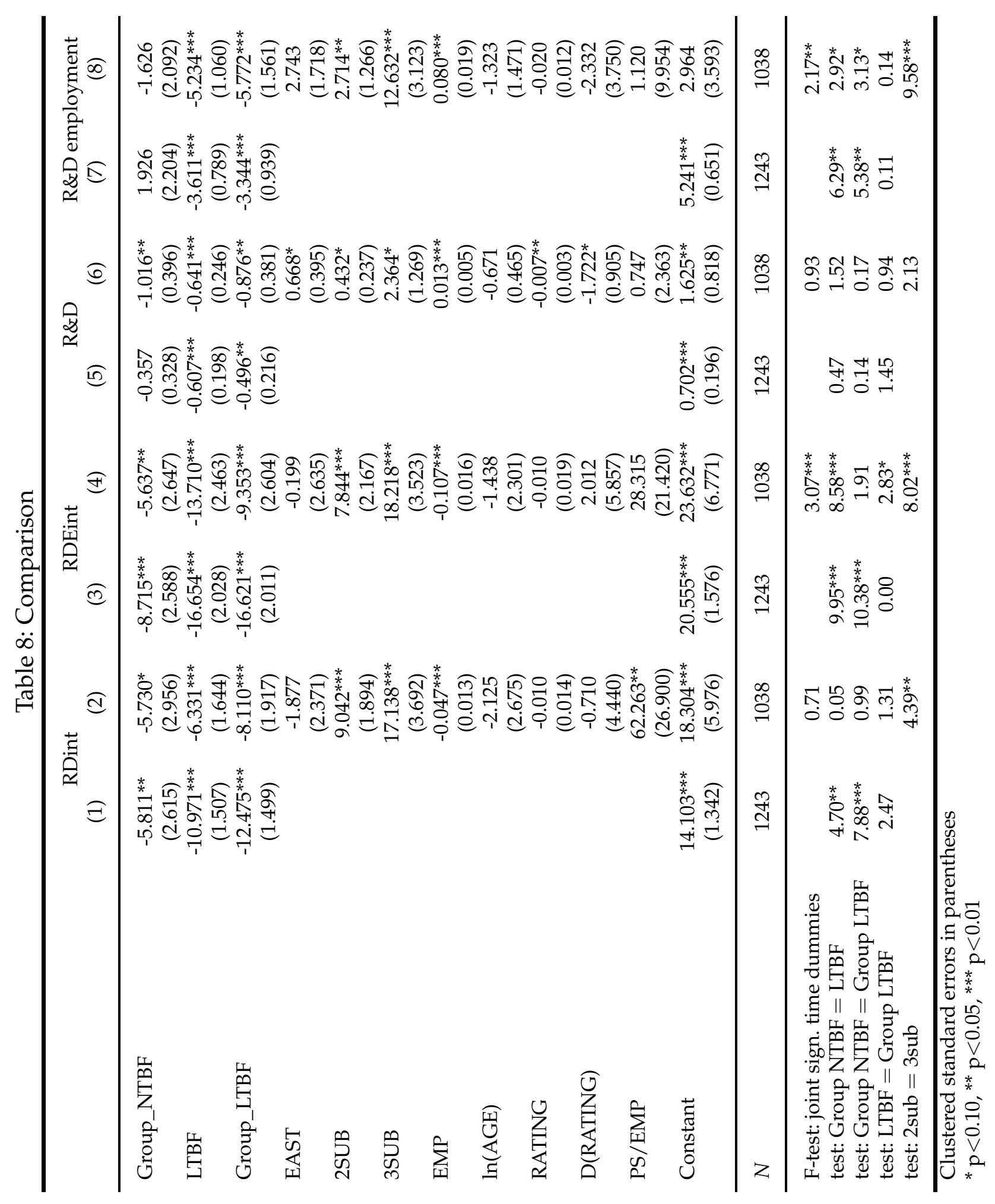


Table 8 presents the results of the treatment effect regressions for the different dependent variables: R\&D intensity, R\&D employment intensity, R\&D expenditures and R\&D employment. For each treatment effect, both the basic regression without additional control variables and the extended regression are presented. Note that all standard errors are clustered at the firm level. The table reveals that the differences between high-tech and low-tech young SMEs in table 8 are only confirmed for independent firms. NTBFs always have a higher input additionality than both LTBFs and Group LTBFs, even after including the control variables in the regressions. For Group NTBFs, we initially also find significant differences compared to LTBFs and Group LTBFs for almost all treatment effects, as can be seen in the tests on differences between coefficients at the bottom of table 8. However, after including the additional control variables in the regression framework, these results change. First, the significant higher increase in R\&D intensity that was found for Group NTBFs compared to LTBFs and Group LTBFs after receiving subsidies becomes insignificant. Similarly, the higher treatment effect for RDEint when comparing Group NTBFs and Group LTBFs becomes insignificant. Only the subsidy-induced increase in R\&D employment remains (weakly) significantly higher when comparing Group NTBFs to all low-tech firm categories.

When focusing solely on low-tech firms, we find at most a very weak significant difference between effects of subsidies on independent and group firms (see tests on differences between coefficients at the bottom of table 8). As a consequence, for low-tech firms, a policy focus on independent young SMEs does not seem to be warranted. For young high-tech SMEs, however, the differentiation between independent firms and group firms seems to matter, although not for all treatment effects. In the basic regressions, the differences are only significant for the treatment effects on the intensity measures (see coefficient of Group NTBF, indicating the relative difference in treatment effects to the reference category of NTBFs, in columns 1 and 3 of Table 8). In the extended regressions, the difference between the $R \& D$ expenditures' treatment effect also become significant (see column 6 of table 8). The results also reveal that the lower treatment effect that was found on R\&D employment for NTBFs as compared to Group NTBFs is insignificant in the basic regression (see column 7). This suggests that Group NTBFs do not make more efficient use of R\&D subsidies in terms of R\&D employment, as was initially indicated by the treatment effects. ${ }^{9}$

\footnotetext{
${ }^{9}$ It has to be noted that the differences between group and independent firms have to be interpreted with caution, as we can only assess the effect of subsidies on the firm surveyed, independent of its other group members. It might well be the case that the effect of subsidies reaches beyond the single group member surveyed and also has an effect on R\&D input of other group members. However, spillover effects are difficult to tackle in input additionality studies and they might as well flow from independent firms to others. It is very
} 
In general, the above findings suggest that high-tech firms and especially the independent ones within this category have higher treatment effects. These findings are re-assuring, as policy makers often target small, young independent firms when launching new policy instruments. Here it is also revealed that it might be relevant to base this decision in a first stage on sector of activity. Only when the focus shifts to high-tech firms, results suggest that NTBFs make more effective use of subsidies than Group NTBFs. However, this latter result should be interpreted with caution as spill-overs to other group members could not be taken into account. In addition, table 7 revealed that full crowding out could be rejected for all firm types studied. As a consequence, although results suggest that high-tech firms increase their R\&D inputs more after receiving subsidies, none of these groups seem to merely replace their private $R \& D$ inputs by public money or seem to simply give higher wages to existing staff without increasing current R\&D employment.

\subsection{The effect on technological progress}

We now turn to the second major research question in this paper, that is, if additionally induced R\&D input leads to technological progress. As already explained above, an increase in $R \& D$ inputs does not necessarily lead to technological progress of the firm. We measure technological progress or performance as the patent activity at the firm level, i.e. the number of patent applications per year (PAT). In this setting, we use R\&D employment intensity as an input factor for the patent production function.

The R\&D employment intensity input factors are based upon the estimated treatment and counterfactual from the matching procedure. $R D E i n t_{i}^{C}$ represents the part of the total R\&D employment intensity that the firms would have had in absence of subsidies. This component of R\&D employment intensity is just equal to the total R\&D employment inten-

sity for the non-subsidized firms. In addition, the treatment effect on the treated $\alpha_{i}^{T T}$ is the additionally induced R\&D employment intensity, as was already introduced in section 5.2. For the non-subsidized firms this variable takes the value zero by construction. In addition to these two R\&D-related variables, we control for industry differences in patenting behavior, and also include time dummies. In addition, we include the log of lagged employment, $\log (\mathrm{EMP})$, and $\log$ of age, $\log (\mathrm{AGE})$, to take possible size and age effects into account. The dummy variable EAST is also inserted in this framework in order to take into account that difficult to evaluate this in our context, however, as we do not have complete information on all other group affiliates. 
patenting activity in the still developing Eastern German region might be lower.

In addition to a pooled cross-sectional QMLE Poisson model, we also estimate the socalled pre-sample mean QMLE poisson model (henceforth PSM) (Blundell et al., 1995, 2002). Unlike in the R\&D input equation where we cannot control for firm-specific effects due to the cross-sectional nature of our database, we can do so when patents are considered, as we were able to collect information on firms' pre-sample patenting activity. One can control for unobserved time-invariant firm-heterogeneity if pre-sample information on the dependent variable is available. Blundell et al. $(1995,2002)$ showed that the unobserved heterogeneity can be approximated by implementing the pre-sample mean of the dependent variable as an additional regressor. This basically amounts to controlling for 'quasi fixed effects'. The pre-sample mean patenting is denoted by PSM.

Table 9 shows the results of this estimation. Note that we lose some observations due to the fact that we only have access to the patent data until 2005. Columns 1-2 show results when not differentiating between different firm categories and columns 3-4 show results when measures of the counterfactual and treatment are inserted separately for the different firm categories. We present bootstrapped standard errors as the R\&D measures of the treated firms are estimated. We used 200 replications of the whole matching procedure and the subsequent estimation of the patent production function to estimate the bootstrap standard errors.

When first focusing on the broad results in columns 1-2, a similar picture as in previous studies emerges (Czarnitzki and Hussinger, 2004). The estimated coefficients of the counterfactual $R \& D$ and the subsidy-induced $R \& D$ are both significantly positive, both for the QMLE poisson and PSM QMLE Poisson estimation. In addition, our results indicate that the coefficient of the counterfactual R\&D is slightly larger than the one of subsidy-induced R\&D, although this result is only weakly significant under the PSM QMLE poisson estimation as shown by the $\chi^{2}$ 's from a likelihood ratio (LR) test.

In columns 3-4, we make a distinction between the four different firm categories by introducing counterfactual $R \& D$ and the subsidy-induced R\&D for all firms separately. All estimated coefficients are positive and significantly different from zero except the one of the subsidy-induced R\&D of Group LTBFs.

Tests show that the hypothesis of equal coefficients of counterfactual and treatment can in general not be rejected within the different firm groups, except for NTBFs. This difference becomes however only weakly significant in the PSM QMLE poisson estimation. 
The more interesting comparison in the context of our study is, however, the different among the coefficients of the subsidy-induced R\&D across the four categories of firm types. There we find that the marginal effect of subsidy-induced R\&D is highest for LTBFs. This, however, does not imply that subsidizing R\&D in this type of firms promises the highest absolute output effects. It has to be taken into account that LTBFs have a lower level of R\&D than e.g. NTBFs and that the estimated input additionality is higher for NTBFs.

In order to get an impression on absolute rather than marginal effects, it is instructive to calculate patent-R\&D elasticities, for instance. The Poisson model has the form $y=\exp \left(x^{\prime} b\right)$. Thus, the elasticity can e.g. be calculated at the mean as

$$
\varepsilon(\widehat{\bar{y}}, \overline{R D})=\hat{b}_{R D} \exp \left(\bar{x}^{\prime} \hat{b}\right) \frac{\overline{R D}}{\exp \left(\bar{x}^{\prime} \hat{b}\right)}=\hat{b}_{R D} \overline{R D}
$$

In our context, we e.g. obtain for the case that an NTBF would not have been subsidized:

Counterfactual output for NTBF: $0.027 \times 12.013=0.3244^{10}$

Because of the subsidy, however, we should add the coefficient of the treatment effect times additionally induced $R \& D$ to the calculation:

$$
0.027 \times 12.013+0.02 \times 20.555=0.7355 .
$$

The subsidy-induced absolute effect in terms of elasticity is thus an increment of 0.411 .

The corresponding effect for LTBFs is, however, only

$$
0.04 \times(11.232-3.901)+0.031 \times 3.901=0.4142,
$$

or in other words the increment due to subsidies is only 0.121 here $(0.031 \times 3.901)$.

Consequently the absolute output gain is larger when subsidizing NTBFs rather than LTBFs despite the larger marginal effect of the additionally induced R\&D for LTBFs. ${ }^{11}$

\section{Conclusion}

Governments acknowledge the fact that especially smaller and younger firms are in need of R\&D subsidies. In light of the 'Europe 2020' strategy, they increasingly focus on 'less and better' state aid, thereby trying to target firms that will most effectively make use of their grants. Frequently, firms in high-tech sectors are preferred in public schemes. Furthermore, the European Commission since recently also emphasizes that especially small- and

\footnotetext{
${ }^{10} 12.013$ is the result of taking average R\&D of subsidized NTBFs, 32.568 (see table 3, descriptive statistics), minus the estimated treatment effect 20.555 (see Table 7).

${ }^{11}$ As already noted multiple times throughout this paper, we abstain from drawing any conclusions on the potential spill-over effects generated by subsidized firms.
} 
Table 9: Estimation of the patent equation for all firm groups ( $\mathrm{N}=2292)$

\begin{tabular}{|c|c|c|c|c|}
\hline & (1) & $(2)$ & (3) & $(4)$ \\
\hline$\alpha_{i}^{T T}$ & $\begin{array}{c}0.020^{* * *} \\
(0.004)\end{array}$ & $\begin{array}{c}0.020^{* * *} \\
(0.004)\end{array}$ & & \\
\hline $\operatorname{RDEint}_{i}^{C}$ & $\begin{array}{c}0.024^{* * *} \\
(0.005)\end{array}$ & $\begin{array}{c}0.024^{* * *} \\
(0.005)\end{array}$ & & \\
\hline$\alpha_{i}^{T T} N T B F$ & & & $\begin{array}{c}0.020^{* * *} \\
(0.005)\end{array}$ & $\begin{array}{c}0.020^{* * *} \\
(0.005)\end{array}$ \\
\hline$\alpha_{i}^{T T} G r o u p \_N T B F$ & & & $\begin{array}{l}0.017^{* *} \\
(0.008)\end{array}$ & $\begin{array}{l}0.018^{* *} \\
(0.008)\end{array}$ \\
\hline$\alpha_{i}^{T T} L T B F$ & & & $\begin{array}{l}0.031^{* *} \\
(0.012)\end{array}$ & $\begin{array}{l}0.032^{* *} \\
(0.013)\end{array}$ \\
\hline$\alpha_{i}^{T T}$ Group_LTBF & & & $\begin{array}{c}0.022 \\
(0.082)\end{array}$ & $\begin{array}{c}0.022 \\
(0.082)\end{array}$ \\
\hline$R_{D E i n t}^{C} N T B F$ & & & $\begin{array}{c}0.027^{* * *} \\
(0.011)\end{array}$ & $\begin{array}{l}0.026^{* *} \\
(0.011)\end{array}$ \\
\hline RDEint $_{i}^{C}$ Group_NTBF & & & $\begin{array}{c}0.012^{* * *} \\
(0.004)\end{array}$ & $\begin{array}{c}0.013^{* * *} \\
(0.004)\end{array}$ \\
\hline $\operatorname{RDEint}_{i}^{C} \operatorname{LTBF}$ & & & $\begin{array}{c}0.040^{* * *} \\
(0.005)\end{array}$ & $\begin{array}{c}0.040^{* * *} \\
(0.005)\end{array}$ \\
\hline RDEint $_{i}^{C}$ Group_LTBF & & & $\begin{array}{c}0.046 \\
(5.450)\end{array}$ & $\begin{array}{c}0.044 \\
(5.192)\end{array}$ \\
\hline EAST & $\begin{array}{l}-0.491^{*} \\
(0.288)\end{array}$ & $\begin{array}{l}-0.521^{*} \\
(0.223)\end{array}$ & $\begin{array}{l}-0.480^{*} \\
(0.289)\end{array}$ & $\begin{array}{l}-0.503^{*} \\
(0.278)\end{array}$ \\
\hline $\ln (\mathrm{EMP})$ & $\begin{array}{c}0.676^{* * *} \\
(0.099)\end{array}$ & $\begin{array}{c}0.649^{* * *} \\
(0.101)\end{array}$ & $\begin{array}{c}0.749^{* * *} \\
(0.101)\end{array}$ & $\begin{array}{c}0.715^{* * *} \\
(0.102)\end{array}$ \\
\hline $\ln (\mathrm{AGE})$ & $\begin{array}{c}0.154 \\
(0.271)\end{array}$ & $\begin{array}{c}0.086 \\
(0.273)\end{array}$ & $\begin{array}{c}0.155 \\
(0.265)\end{array}$ & $\begin{array}{c}0.090 \\
(0.268)\end{array}$ \\
\hline PRESAM & & $\begin{array}{c}0.197 \\
(0.203)\end{array}$ & & $\begin{array}{c}0.185 \\
(0.203)\end{array}$ \\
\hline Constant & $\begin{array}{c}-4.246^{* * *} \\
(0.921)\end{array}$ & $\begin{array}{c}-3.986^{* * *} \\
(0.907)\end{array}$ & $\begin{array}{c}-4.331^{* * *} \\
(0.915)\end{array}$ & $\begin{array}{c}-4.051^{* * *} \\
(0.895)\end{array}$ \\
\hline $\begin{array}{l}\chi^{2} \text { test on joint significance of time dummies } \\
\chi^{2} \text { test on joint significance of industry dummies }\end{array}$ & $\begin{array}{l}42.42^{* * *} \\
176.87^{* * *}\end{array}$ & $\begin{array}{l}63.13^{* * *} \\
150.84^{* * *}\end{array}$ & $\begin{array}{l}50.01^{* * *} \\
186.44^{* * *}\end{array}$ & $\begin{array}{l}68.92^{* * *} \\
163.35^{* * *}\end{array}$ \\
\hline$\chi^{2}$ LR test: $\alpha_{i}^{T T}=R D E$ Eint $t_{i}^{C}$ & $4.70^{* *}$ & $3.56^{*}$ & & \\
\hline$\chi^{2}$ LR test: $\operatorname{RDEint}_{i}^{C} N T B F=\alpha_{i}^{T T} N T B F$ & & & $4.76^{* *}$ & $2.86^{*}$ \\
\hline$\chi^{2}$ LR test: $R D$ Eint $i_{i}^{C}$ Group_NTBF $=\alpha_{i}^{T T}$ Group_NTBF & & & 1.90 & 2.07 \\
\hline$\chi^{2}$ LR test: $R D$ Eint $_{i}^{C} L T B F=\alpha_{i}^{T T} L T B F$ & & & 1.60 & 1.24 \\
\hline$\chi^{2}$ LR test: $R D$ Eint ${ }_{i}^{C}$ Group $\_L T B F=\alpha_{i}^{T T}$ Group $\_L T B F$ & & & 0.27 & 0.24 \\
\hline
\end{tabular}


medium-sized, young, stand-alone high-tech firms make possibly the most effective use of public funds. Thus, firms associated with groups of firms have less access to subsidies than in the past. While these policies thus give a clear preference to a certain type of firms, it is surprising that so far no systematic impact evaluation of such policies exists. Consequently, in this study, we compare the effect of innovation subsidies on New Technology Based Firms (NTBF), Low Technology Based Firms (LTBFs) and their group counterparts for a sample of German firms. NTBFs are young independent high-tech SMEs, while LTBFs are the corresponding firms in low-tech sectors. We denote their non-independent counterparts by 'Group NTBFs' and 'Group LTBFs'.

In a first stage, we estimate the input additionality effects for each of these firm types, i.e. we analyze the policy impact on firms' R\&D intensity, R\&D expenditures, R\&D employment intensity and $R \& D$ employment numbers. Considering these firm types separately in our empirical analysis also enables us to compare the estimated treatment effects among these groups. In a second stage, we turn to the effect subsidies have on innovation output as measured by patents.

In order to evaluate the impact of innovation subsidies on the innovation input of NTBFs, Group NTBFs, LTBFs and Group LTBFs, caliper matching with replacement is applied in order to correct for a potential selection bias. In general, our results reveal that full crowdingout with regard to public funding can be rejected for all firm types studied.

In order to assess the potential differences in subsidy effects, we compare the treatment effects of the different firm types by regressing the individual treatment effects on the different firm types and additional control variables. Our results reveal that the treatment effects on independent NTBFs are actually highest, as presumed by policy makers. Thus our empirical study does not only support the currently common choice to give a preferential treatment to small, young and independent firms active in high-tech sectors, but also provides evidence that previous estimations of innovation policy impacts might have been partly misleading as usually no distinction between preferential firm profiles in policy schemes have been made.

In a second step, we carry the results of the treatment effects analysis over to the estimation of a patent production function, where R\&D employment intensity is disentangled into two components: on the one hand, the purely privately R\&D employment intensity in the absence of subsidies and, on the other hand, the additionally induced R\&D employment intensity that is stimulated by the subsidy. Results of this estimation reveal that due to in- 
creased R\&D input that was found in a first step, also higher R\&D output is achieved by the subsidized firms.

Of course, our study has a number of limitations that remain for further research. First, we only consider Germany as an example of a European economy. It is questionable whether our results hold for other countries within the European community. In addition, the analysis on input additionality would benefit from the availability of panel data to control for firm fixed effects. Longer time series of data would allow investigating the effect of $R \& D$ subsidies on a wider range of R\&D output indicators. Next to these limitations related to the time-structure of the data, we could only assess whether a firm has received a subsidy or not, without being able to assess potential heterogeneities in the grants. Although we already introduced information on different subsidy sources, we do not know how much aid is actually given to a firm. Introducing this latter aspect in the estimations would be very interesting for further research. 


\section{References}

Acs, Z. and Audretsch, D. (1989), 'Small-firm entry in US manufacturing', Economica 56, 255-265.

Alecke, B., Mitze, T., Reinkowski, J. and Untiedt, G. (2012), 'Does firm size make a difference? Analysing the effectiveness of R\&D subsidies in East Germany', German Economic Review 13, 174195.

Almus, M. and Nerlinger, E. (1999), 'Growth of New Technology Based Firms: which factors matter?', Small Business Economics 13, 141-154.

Angrist, J. (1998), 'Estimating the labor market impact of voluntary military service using social security data', Econometrica 66, 249-288.

Arrow, K. (1962), Economic welfare and the allocation of resources for invention, in R. Nelson, ed., 'The rate and direction of inventive activity: economic and social factors', Princeton University Press, pp. 609-625.

Audretsch, D. (1995), 'Innovation, growth and survival', International Journal of Industrial Organization 13, 441-457.

Bartelsman, E., Haltiwanger, J. and Scarpetta, S. (2004), 'Microeconomic evidence of creative destruction in industrial and developing countries', Discussion Papers 04-114/3, Tinbergen Institute .

Berger, A. and Udell, G. (2002), 'Small business credit availability and relationship lending: the importance of bank organisational structure', The Economic Journal 112, 32-53.

Blundell, R., Griffith, R. and Van Reenen, J. (1995), 'Dynamic count data models of technological innovation', The Economic Journal 105, 333-344.

Blundell, R., Griffith, R. and Windmeijer, F. (2002), 'Individual effects and dynamics in count data models', Journal of Econometrics 108, 113-131.

BMBF (Federal Ministry of Education and Research) (2010), 'Ideas. Innovation. Prosperity. High-tech strategy 2020 for Germany'.

Branstetter, L. and Sakakibara, M. (2002), 'When do reserach consortia work well and why? evidence from Japanese panel data', American Economic Review 92, 143-159.

Calvo, J. (2006), 'Testing Gibrat's law for small, young and innovating firms', Small Business Economics 26, 117-123.

Carpenter, R. and Petersen, B. (2002), 'Capital market imperfections, high-tech investment, and new equity financing', The Economic Journal 112(477), F54-F72.

Cassar, G. (2004), 'The financing of business start-ups', Journal of Business Venturing 19(2), 261-283.

Cerulli, G. (2010), 'Modelling and measuring the effect of public subsidies on business R\&D: A critical review of the econometric literature', The Economic Record 86, 421-449.

Cochran, W. and Rubin, D. (1973), 'Controlling bias in oberservational studies: a review', Sankhya Ser. A $35,417-446$.

Colombo, M. G., Giannangeli, S. and Grilli, L. (2012), 'Public subsides and the employment growth of high-tech start-ups: assessing the impact of selective and automatic support schemes', Industral and Corporate Change 22, 1273-1314. 
Colombo, M. G. and Grilli, L. (2010), 'On growth drivers of high-tech start-ups: Exploring the role of founders' human capital and venture capital', Journal of Business Venturing 25(6), 610-626.

Colombo, M. G., Grilli, L. and Murtinu, S. (2011), 'R\&D subsidies and the performance of high-tech start-ups', Economics Letters 112, 97-99.

Cozza, C., Malerba, F., Mancusi, M. L., Perani, G. and Vezzulli, A. (2012), 'Innovation, profitability and growth in medium and high-tech manufacturing industries: evidence from Italy', Applied Economics 44, 1963-1976.

Czarnitzki, D. and Delanote, J. (2013), 'Young innovative companies: the new high-growth firms?', Industrial and Corporate Change 22(5), 1315-1340.

Czarnitzki, D., Ebersberger, B. and Fier, A. (2007), 'The relationship between R\&D collaboration, subsidies and R\&D performance: empirical evidence from Finalnd and Germany', Journal of Applied Econometrics 22, 1347-1366.

Czarnitzki, D. and Hottenrott, H. (2011), 'R\&D investment and financing constraints of small and medium-sized firms', Small Business Economics 36, 65-83.

Czarnitzki, D. and Hussinger, K. (2004), 'The link between R\&D subsidies, R\&D spending and technological performance', ZEW working paper, 4-56.

Czarnitzki, D. and Licht (2006), 'Additionality of Public R\&D Grants in a Transition Economy: the Case of Eastern Germany', The Economics of Transition 14, 101-131.

Czarnitzki, D. and Lopes Bento, C. (2014), 'Innovation Subsidies: Does the Funding Source Matter for Innovation Intensity and Performance? Empirical Evidence from Germany', Industry and Innovation 21, 380-409.

David, P., Hall, B. and Toole, A. (2000), 'Is public R\&D a complement or substitute for private R\&D? a review of the econometric evidence', Research Policy 29, 497-529.

Dehejia, R. and Wahba, S. (1999), 'Causal effects in nonexperimental studies: reevaluating the evaluation of training programs', Journal of the American Statistical Association 94, 1053-1062.

Dixit, A. K. and Pindyck, R. S. (1994), Investment under Uncertainty, Princeton University Press.

Dunne, T., Roberts, M. and Samuelson, L. (1988), 'Patterns of firm entry and exit in US manufacturing industries', The RAND Journal of Economics pp. 495-515.

EC-DG Research and Innovation (2011), 'State of the innovation union'.

European Commission (2008), ‘Commission Regulation (EC) No 800/2008 of 6 August 2008 declaring certain categories of aid compatible with the common market in application of Articles 87 and 88 of the Treaty (General block exemption Regulation) (Text with EEA relevance)', Official Journal L.214, 9.8.2008 pp. 3-47.

Evans, D. and Jovanovic, B. (1989), 'An estimated model of entrepreneurial choice under liquidity constraints', Journal of Political Economy 97, 808-827.

Goodacre, A. and Tonks, I. (1995), Finance and technological change, in P. Stoneman, ed., 'Handbook of the economics of innovation and technological change', Oxford: Blackwells, pp. 298-341.

Goolsbee, A. (1998), 'Does R\&D Policy primarily benefit scientists and engineers?', American Economic Review 88, 298-302. 
Griliches, Z. (1990), 'Patent statistics as economic indicators: a survey', Journal of Economic Literature 28, 1661-1707.

Griliches, Z. (1998), Patent statistics as economic indicators: a survey, in 'R\&D and productivity: the econometric evidence', University of Chicago Press, pp. 287-343.

Griliches, Z. and Mairesse, J. (1984), Productivity and R\&D at the firm level, in Z. Griliches, ed., 'R\&D, Patents and Productivity', University of Chicago Press: Chicago, IL.

Grilli, L. and Murtinu, S. (2012), 'Do public subsidies affect the performance of new technology-based firms? the importance of evaluation schemes and agency goals', Prometheus: Critical Studies in Innovation 30, 97-111.

Hall, B. (1990), 'The impact of corporate restructuring on industrial research and development', Brooking Papers on Economic Activity 1, 85-136.

Hall, B., Griliches, Z. and Hausman, J. (1986), 'Patents and R\&D: is there a lag?', International Economic Review 27, 1029-1054.

Hall, B. and Lerner, J. (2010), Chapter 14: The financing of R\&D and innovation, in B. Hall and N. Rosenberg, eds, 'Economics of Innovation', Elsevier: Oxford.

Heckman, J., Ichimura, H., Smith, J. and Todd, P. (1998), 'Characterizing selection bias using experimental data', Econometrics 66, 1017-1098.

Himmelberg, C. and Petersen, B. (1994), 'R\&D and internal finance: a panel study of small firms in high-tech sectors', Review of Economics and Statistics 76, 38-51.

Holtz-Eakin, D., Joulfaian, D. and Rosen (1994a), 'Sticking it out: Entrepreneurial survivial and liquidity constraints', Journal of Political Economy 102, 53-75.

Holtz-Eakin, D., Joulfaian, D. and Rosen, H. (1994b), 'Entrepreneurial decisions and liquidity constraints', Rand Journal of Economics 25, 334-347.

Hoshi, T., Kashyap, A. and Scharfstein, D. (1991), 'Corporate structure, liquidity, and investment: evidence from Japanese industrial groups', The Quarterly Journal of Econnomics 106, 33-60.

Howells, J. (2008), 'New directions in R\&D: current and prospective challenges', RED Management $38,241-252$.

Jaffe, A. (1986), 'Technological opportunity and spillovers of R\&D: evidence from firm's patent, profits, and market value', American Economic Review 76, 984-1001.

Lechner, M. (2000), 'An evaluation of public sector sponsored continuous vocational training in East Germany', Journal of Human Resources 35, 347-375.

Lechner, M. (2001), Identification and estimation of causal effects of multiple treatments under the Conditional Independence Assumption, in M. Lechner and F. Pfeiffer, eds, 'Econometric Evaluatoin of Labour Market Policies', Physica, pp. 43-58.

Lerner, J. (1999), 'The government as venture capitalist: the long-run impact of the SBIR program', Journal of Business 72(3), 285-318.

Lerner, J. (2002), 'When bureaucrats meet entrepreneurs: the design of effective 'public venture capital' programmes', The Economic Journal 112(477), F73-F84.

Licht, G. and Nerlinger, E. (1998), 'New technology-based firms in Germany: a survey of the recent evidence', Research Policy 26, 1005-1022. 
Little, A. D. (1977), 'New technology-based firms in the United Kingdom and the Federal Republic of Germany', A report prepared for the Anglo-German foundation for the study of industrial society, London .

Moncada, P., Ciupagea, C., Smith, K., Tuebke, A. and Tubbs, M. (2010), 'Does Europe perform too little corporate R\&D? a comparison of EU and non-EU corporate R\&D performance', Research Policy 39, 523-536.

Nelson, R. (1959), 'The simple economics of basic scientific research', Journal of Political Economy 49, 297-306.

OECD (1994), 'The measurement of scientific and technological activities - using patent data as science and technology indicators: patent manual 1994, Paris'.

Pakes, A. and Griliches, Z. (1984), 'Estimating distributed lags in short panels with an application to the specification of depreciation patterns and capital stock constructs', NBER working paper series 0933, NBER, Cambridge .

Pindyck, R. (1991), 'Irreversibility, uncertainty, and investment', Journal of Economic Literature 29, 1110-1148.

Rosenbaum, P. and Rubin, D. (1983), 'The central role of the propensity score in observational studies for causal effects', Biometrika 70, 41-55.

Rubin, D. (1977), 'Assignment to treatment group on the basis of covariate', Journal of Educational Statistics 2, 1-26.

Schaller, H. (1993), 'Asymmetric information, liquidity constraints, and Canadian Investment', The Canadian Journal of Economics 26, 552-574.

Schneider, C. and Veugelers, R. (2010), 'On young highly innovative companies: why they matter and how (not) to policy support them', industrial and Corporate Change 19(4), 1-39.

Schumpeter, J. (1942), Capitalism, Socialism and Democracy, New York, Harper and Row.

Stiglitz, J. and Weiss, A. (1981), 'Credit Rationing in Markets with Imperfect Information', American Economic Review 71, 393-410.

Storey, D. and Tether, B. (1998), 'New technology-based firms in the european union: an introduction', Research Policy 26(9), 933 - 946.

Veugelers, R. (2008), 'The role of SMEs in innovation in the EU: a case for policy intervention?', Review of Business and Economics 53(3), 239-262.

Wallsten, S. (2000), 'The effects of government-industry R\&D programs on private R\&D: the case of the Small Business Innovation Research Program', RAND Journal of Economics 31, 82-100.

Westhead, P. and Cowling, M. (1995), 'Employment change in independent owner-managed hightechnology firms in Great Britain', Small Business Economics 7, 111-140.

Westhead, P. and Storey, D. (1997), 'Financial constraints on the growth of high technology small firms in the United Kingdom', Applied Financial Economics 7, 197-201.

Wooldridge, J. (2002), Chapter 19: Count data and related models, in 'Econometric Analysis of cross section and panel data.', MIT press.

Zúñiga Vicente, J., Alonso-Borrego, C., Forcadell, F. and Galan, J. (2014), 'Assessing the effect of public subsidies on firm R\&D investment: a survey', Journal of Economic Surveys 28, 36-67. 


\section{Appendix}

Table A1: Industry structure

\begin{tabular}{|c|c|c|c|}
\hline Industry & Description & NTBF & $\begin{array}{l}\text { group } \\
\text { NTBF }\end{array}$ \\
\hline 1 & $\begin{array}{l}\text { Manufacture of chemicals and chemical products ;Man- } \\
\text { ufacture of pharmaceuticals, medicinal chemicals and } \\
\text { botanical products }\end{array}$ & 88 & 61 \\
\hline 2 & $\begin{array}{l}\text { Manufacture of machinery and equipment n.e.c.; Manu- } \\
\text { facture of motor vehicles, trailers and semi-trailers; Manu- } \\
\text { facture of other transport equipment; Building and repair- } \\
\text { ing of ships and boats ; Manufacture of aircraft and space- } \\
\text { craft; }\end{array}$ & 235 & 132 \\
\hline 3 & $\begin{array}{l}\text { Manufacture of office machinery and computers; Manu- } \\
\text { facture of electrical machinery and apparatus n.e.c.; Manu- } \\
\text { facture of radio, television and communication equipment } \\
\text { and apparatus; Manufacture of medical, precision and op- } \\
\text { tical instruments, watches and clocks; }\end{array}$ & 272 & 141 \\
\hline 4 & Research and development; Other Business activities & 465 & 179 \\
\hline \multirow[t]{3}{*}{5} & Computer and related activities & 168 & 96 \\
\hline & Total number of Observations: & 1288 & 609 \\
\hline & & LTBF & $\begin{array}{l}\text { Group } \\
\text { LTBF }\end{array}$ \\
\hline 6 & Manufacture of food products, beverages and tobacco & 42 & 23 \\
\hline 7 & Manufacture of textiles & 61 & 21 \\
\hline 8 & $\begin{array}{l}\text { Manufacture of wood and wood products; manufacture of } \\
\text { pulp, paper and paper products; publishing and printing; }\end{array}$ & 65 & 35 \\
\hline 9 & $\begin{array}{l}\text { Manufacture of coke, refined petroleum products and nu- } \\
\text { clear fuel; Manufacture of rubber and plastic products }\end{array}$ & 89 & 48 \\
\hline 10 & Manufacture of basic metals and fabricated metal products & 179 & 59 \\
\hline 11 & $\begin{array}{l}\text { Fishing; mining and quarrying; Mineral products; Furni- } \\
\text { ture; other industries; Waste collection, treatment and dis- } \\
\text { posal activities; materials recovery; Other services }\end{array}$ & 243 & 132 \\
\hline 12 & $\begin{array}{l}\text { Wholesale and retail trade and repair of motor vehicles } \\
\text { and motorcycles }\end{array}$ & 133 & 50 \\
\hline 13 & Transportation, storage ; Financial and insurance activities & 137 & 89 \\
\hline \multirow[t]{2}{*}{14} & Communication services & 16 & 13 \\
\hline & Total number of Observations: & 965 & 470 \\
\hline
\end{tabular}

